\title{
Assessment of microalbuminuria in hypertensive patients with established coronary artery disease
}

\author{
Evaluarea microalbuminuriei la pacienți hipertensivi cu \\ boală coronariană instalată
}

\author{
Delia L. Şalaru*, Liviu Macovei, Cristian Stătescu, Cătălina Arsenescu-Georgescu \\ Institute of Cardiovascular Diseases "Prof. Dr. George I.M. Georgescu", Iaşi and \\ University of Medicine and Pharmacy "Gr. T. Popa", Iaşi
}

\begin{abstract}
Objectives. Cardiovascular risk assessment is continuously improving due to a better understanding of the atherosclerotic pathomechanism by investigating new risk factors. Microalbuminuria is known as a predictor of renal, as well as cardiovascular morbidity and mortality in patients with hypertension. The aim of this study was to determine the clinical relevance of microalbuminuria and its relationship with traditional cardiovascular risk factors in hypertensive high-risk patients with established coronary artery disease. Methods. We have collected clinical and laboratory data from 94 hypertensive patients (currently treated or newly diagnosed) with known coronary artery disease (angiographically documented) admitted in the Institute of Cardiovascular Diseases. From January 2012 to April 2013 they were screened for microalbuminuria. For the diagnosis of microalbuminuria, a first-morning urine sample was analyzed by immunoturbidimetry (MAU range: 20-200 mg/l, the microalbuminuric group). Patients with urinary albumin excretion $>200 \mathrm{mg} / \mathrm{l}$ were excluded. Patients with values $<20 \mathrm{mg} / \mathrm{l}$ were considered the normoalbuminuric group. Results. A large percentage (53.2\%) of the study group was found with microalbuminuria. Patients with microalbuminuria were older, mostly male, with a longer duration of hypertension, and with a higher prevalence of left ventricular hypertrophy (LVH). None of the traditional cardiovascular risk factors - age, male gender, obesity, smoking, diabetes mellitus, dyslipidemia - indicated a statistical significance in relation with MAU. Although left ventricular ejection fraction (LVEF) didn't influence the level of microalbuminuria, a strong correlation was achieved with the presence of LVH $(p=0.005)$ and duration of hypertension $(p=0.046)$. Conclusion. Hypertensive high-risk patients should be routinely screened for microalbuminuria and when confirmed they may need a more aggressive medical therapy to lower the cardiovascular risk.
\end{abstract}

Keywords: microalbuminuria; hypertension; coronary artery disease.

\section{Rezumat}

Obiective. Evaluarea riscului cardiovascular este îmbunătățită continuu datorită unei mai bune înțelegeri a patomecanismului aterosclerotic prin investigarea de noi factori de risc. Microalbuminuria este

*Corresponding author: Delia L Şalaru, MD, PhDs, Department of Cardiology, Institute of Cardiovascular Diseases "Prof. Dr. George I.M. Georgescu", Bd. Carol I, Nr. 50, Iaşi, Romania

Phone: 0040-740301781, E-mail: deliasalaru@gmail.com 
recunoscută ca predictor de morbiditate şi mortalitate renală, dar şi cardiovasculară la pacienții hipertensivi. Scopul acestui studiu a fost de a determina relevanța clinică a microalbuminuriei şi relația sa cu factorii de risc cardiovascular tradiționali la pacienții hipertensivi cu risc foarte înalt şi boală coronariană stabilită. Metode. Am colectat datele clinice şi de laborator de la 94 de pacienți hipertensivi (aflați sub tratament sau nou diagnosticați) cu boală coronariană cunoscută (documentată angiografic) internați în Institutul de Boli Cardiovasculare în perioada ianuarie 2012 - aprilie 2013. Pentru diagnosticul de microalbuminurie s-a analizat o probă din prima urină de dimineață prin imunturbidimetrie (valori de referință 20-200 mg/l, grupul microalbuminuric). Pacienții cu excreție urinară de albumină $>200 \mathrm{mg} / \mathrm{l}$ au fost excluşi. Pacienții cu valori $<20$ mg/l au fost considerați grupul normoalbuminuric. Rezultate. Un procent înalt (53.2\%) din populația de studiu a fost găsit cu microalbuminurie. Pacienții cu microalbuminurie au fost mai în vârstă, majoritatea bărbați, cu o durată mai lungă a hipertensiunii şi cu o prevalență mai înaltă a hipertrofiei ventriculare stângi. Nici unul dintre factorii de risc cardiovascular tradiționali - vârsta, sexul masculin, obezitatea, fumatul, diabetul zaharat, dislipidemia - nu a atins semnificația statistică în relație cu microalbuminuria. Deşi fracția de ejecție a ventriculului stâng nu a influențat nivelul microalbuminuriei, o corelație strânsă s-a obținut cu prezența hipertrofiei ventriculare stângi $(p=0.005)$ şi cu durata hipertensiunii $(p=0.046)$. Concluzii. Pacienții hipertensivi cu risc înalt ar trebui testați de rutină pentru microalbuminurie şi când aceasta este confirmată, ar putea necesita o terapie medicală mai agresivă pentru scăderea riscului cardiovascular.

Cuvinte cheie Microalbuminurie; hipertensiune arterială; boală coronariană ischemică.

Received: $4^{\text {th }}$ June 2013; Accepted: 27 ${ }^{\text {th }}$ October 2013; Published: $9^{\text {th }}$ December 2013.

\section{Introduction}

Microalbuminuria, an abnormal increase in the rate of urinary excretion of albumin, is recognized as an early manifestation of diabetic kidney disease and as a marker of endothelial dysfunction and atherosclerotic disease. In addition, a large number of studies suggest that microalbuminuria (MAU) is a powerful independent predictor of microvascular lesions, cardiovascular disease (1), cardiovascular mortality, and kidney disease, including end-stage renal failure. Albuminuria is an early marker of diabetic nephropathy, and previous reports described the association between albuminuria and risk of adverse cardiovascular and kidney events $(2,3)$. Both the presence of microalbuminuria and its extent became valuable instruments for risk stratification of hypertensive patients (4), since large trials showed conclusive evidence that early determination and treatment of microalbuminuria, as well as blood pressure control, can delay the onset and the complications of cardiovascular disease $(5,6)$.

In hypertensive subjects, MAU has often been related to an excess of atherosclerotic car- diovascular disease $(7,8)$, and to an increased level of atherosclerotic risk markers (9). The relationship between MAU and the development of vascular disease is strengthened by its presence in acute ischemic heart disease (10), congestive heart failure (11), stroke (12), peripheral arterial disease, and carotid atherosclerosis (13). Thus, MAU might serve as a 'diagnostic window' for the whole vasculature, acting as an indicator of generalized endothelial injury $(4,14)$.

In the present study we aimed to investigate the clinical relevance of MAU in high-risk hypertensive patients with established coronary heart disease, and to underline the significant correlations with traditional cardiovascular risk factors.

\section{Methods}

\section{Patients}

94 patients with arterial hypertension (currently treated or newly diagnosed) and of known coronary artery disease (angiographically documented), admitted in the Institute of Cardiovascular Diseases from January 2012 to April 2013, were screened for microalbumin- 
uria. MAU was measured in all patients except for those with fever $\left(>38^{\circ} \mathrm{C}\right)$, renal disease (eGFR $<60 \mathrm{ml} / \mathrm{min} / 1.73 \mathrm{~m}^{2}$, Cockroft-Gault formula), urinary tract infection or having practiced extensive physical effort $24 \mathrm{~h}$ before the measurement. All patients gave written informed consent for participating in the study. The study was in accordance with the ethical principles of the Declaration of Helsinki and was approved by the local ethics committee.

\section{Study design and procedures}

Collected baseline data of the patients included medical history, demographics, biometric data, urine and blood collections, and laboratory analysis. For the diagnosis of microalbuminuria, a first-morning urine sample was analyzed by immunoturbidimetry (MAU range: $20-200 \mathrm{mg} / \mathrm{l}$, the microalbuminuric group). Patients with urinary albumin excretion $>200 \mathrm{mg} / \mathrm{l}$ were excluded. Patients with values $<20 \mathrm{mg} / \mathrm{l}$ were considered the normoalbuminuric group.

Hypertension was defined as systolic blood pressure $>140 \mathrm{~mm} \mathrm{Hg}$, diastolic blood pressure $>90 \mathrm{~mm} \mathrm{Hg}$, and/or use of antihypertensive drugs. Dyslipidemia was defined as cholesterol $>$ $180 \mathrm{mg} / \mathrm{dl}$ and/or HDL $<40 \mathrm{mg} / \mathrm{dl}$ in male patients and $<50 \mathrm{mg} / \mathrm{dl}$ in female patients and/or LDL > $160 \mathrm{mg} / \mathrm{dl}$ and/or triglycerides > 150 $\mathrm{mg} / \mathrm{dl}$ and/or use of lipid-lowering treatment. Obesity was defined as BMI $>=30 \mathrm{~kg} / \mathrm{m}^{2}$. Diabetes was defined as fasting plasma glucose levels $>126 \mathrm{mg} / \mathrm{dl}$ and/or use of antidiabetic therapy.

Left ventricular hypertrophy (LVH) and left ventricular ejection fraction (LVEF) were assessed echocardiographically by a single investigator. LVH was defined as posterior wall thickness or/and interventricular septum thickness > $12 \mathrm{~mm}$ (M-Mode measurement). Left ventricular ejection fraction (LVEF) was determined using the Sympson method.

\section{Statistical methods}

Results are presented as mean \pm SD for continuous variables and as percentages of the total number of patients for categorical variables. Correlation analysis was conducted using
Pearson (r) or Spearman $(\rho)$ tests. The data were also logarithmically transformed to achieve normal distribution, whenever possible. We performed univariate analysis using a $t$-test for normally distributed continuous variables and Mann-Whitney test if variables were not normally distributed. Comparisons of categorical variables were analyzed by the Chi-square test. A P value $\leq 0.05$ was considered significant. Statistical analysis was performed with SPSS 21.0 (SPSS Inc., Chicago, IL, USA).

\section{Results}

Clinical and biological characteristics of the study population are presented in Table 1 . Laboratory results from urine showed that an important percentage $(53.2 \%)$ of our study group represented by high-risk hypertensives had evidence of MAU. Patients with microalbuminuria were older, mostly male, with a longer duration of hypertension, and with a higher prevalence of left ventricular hypertrophy. An important proportion was dyslipidemic (80\%).

A correlation analysis was performed to assess the relationship of microalbuminuria with traditional risk factors: male gender $(\mathrm{p}=0.48)$, age ( $p=0.07)$, smoking $(p=0.139)$, diabetes mellitus $(\mathrm{p}=0.75), \quad$ dyslipidemia $\quad(\mathrm{p}=0.406), \quad$ obesity $(\mathrm{p}=0.837)$. None of them showed a statistical significance. Microalbuminuria and serum levels of glucose and lipids didn't show any correlation $(\rho=$ 0.002 and 0.041 , respectively). Microalbuminuria was not influenced by eGFR ( $\mathrm{p}=0.249)$. LVEF values didn't reach a statistical significance in relationship with microalbuminuria $(\mathrm{p}=0.824)$. However, a strong correlation was achieved with the presence of left ventricular hypertrophy ( $\mathrm{p}=0.005$, Figure 1$)$ and duration of hypertension $(\mathrm{p}=0.046)$.

\section{Discussion}

First of all, this study shows a high prevalence of microalbuminuria among patients with coronary artery disease, supporting the ex- 
Table 1. Clinical and biological characteristics of the study population

\begin{tabular}{lccc}
\hline & $\begin{array}{c}\text { Normoalbuminuric group } \\
\mathbf{n = 4 4}\end{array}$ & $\begin{array}{c}\text { Microalbuminuric group } \\
\mathbf{n = 5 0}\end{array}$ & p-value \\
\hline Age, y & $60(50-72)$ & $62.5(55-75)$ & 0.29 \\
Male, \% & $54.50 \%$ & $60 \%$ & 0.67 \\
Smokers, \% & $56.80 \%$ & $46 \%$ & 0.31 \\
Hypertension, y & $5(2-9)$ & $6(3-10.25)$ & 0.26 \\
Dyslipidemia, \% & $77.30 \%$ & $80 \%$ & 0.8 \\
Diabetes mellitus, \% & $52.30 \%$ & $44 \%$ & 0.53 \\
Obesity, \% & $36.40 \%$ & $46 \%$ & 0.4 \\
LVH, \% & $50 \%$ & $66 \%$ & 0.144 \\
EF (\%) & $45(35-50)$ & $45(40-50)$ & 0.676 \\
Laboratory data & & & \\
Glucose (mg/dl) & $117(105-180)$ & $108(100.25-173)$ & 0.179 \\
HDL-C (mg/dl) & $50(32-59)$ & $48(38.75-54)$ & 0.964 \\
LDL-C (mg/dl) & $113(95-164)$ & $119(93-139)$ & 0.578 \\
Cholesterol (mg/dl) & $185(159-221)$ & $193(163.5-215.25)$ & 0.894 \\
Triglycerides (mg/l) & $154(108-200)$ & $118(73-212.25)$ & 0.1 \\
eGFR (ml/min/1.73m2) & $89.6(64.3-117.97)$ & $84.65(68.64-99.75)$ & 0.74 \\
Microalbuminuria (mg/l) & $10.12(6.21-15.77)$ & $48.65(30.62-87.06)$ & \\
Log microalbuminuria & $1(0.78-1.19)$ & $1.68(1.48-1.93)$ & \\
\hline
\end{tabular}

tent of the generalized state of inflammation and endothelial dysfunction. Previous studies report a prevalence of microalbuminuria in patients with hypertension and diabetes of $10 \%$ to $15 \%$ and $15 \%$ to $20 \%$, respectively, which is higher than the prevalence in individuals from the general population in whom values of $6 \%$ to $8 \%$ have been described $(15,16)$.

The increased cardiovascular risk of hypertensive patients, together with a higher mortality rate in the general population, are closely related to the comorbidities and risk factors that accompany this pathology. In the I-SEARCH study, both microalbuminuria itself and its value increased significantly with the number of associated morbid conditions, suggesting that endothelial dysfunction and the addition of pathological disorders go well together (17).
Copenhagen City Heart study revealed a strong correlation between microalbuminuria and the metabolic syndrome (18), showing that MAU is associated with increased risk of death and cardiovascular disease to a similar extent as the metabolic syndrome, irrespective of its concomitant presence. Our study population has a high prevalence of the components of metabolic syndrome, however we did not assess its influence separately.

Our findings are in line with data from the I-SEARCH study, where patients with left ventricular hypertrophy presented, in $68 \%$ of the cases, microalbuminuria (17). LVH, as a sign of target organ damage, is a strong and independent predictor of both cardiovascular events and all-cause mortality in patients with hypertension (19). Therefore, patients diagnosed with left ventricular hypertrophy (electro- 


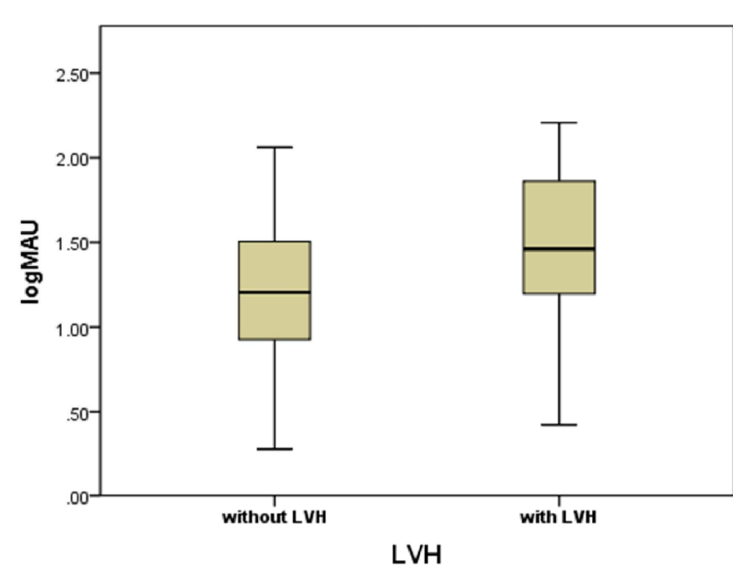

Figure 1. Relationship between the level of microalbuminuria $(\log M A U)$ and the presence of left ventricular hypertrophy (LVH)

cardiographically or echocardiographically) should be thoroughly investigated, keeping in mind the likelihood of a coronary disease.

Data from the HOPE study suggested that any level of microalbuminuria predicts coronary heart disease in individuals with or without diabetes (20), and furthermore MAU is a strong determinant of coronary artery disease and death independently of age, sex, hypertension, diabetes mellitus, renal function, and lipids (21). It has been proven that the majority of cardiovascular events don't necessarily occur in patients with high blood pressure, therefore it is important to detect and to treat hypertension as early as possible (22).

MAU reflects widespread vascular damage and is associated with the presence of an unfavorable risk score and target organ damage. However, the pathophysiological link between MAU and coronary artery disease is not yet elucidated. Accumulative evidence suggests that the pathological changes causing MAU and the pathological changes leading to premature atherosclerosis are the same. Decreased density of heparan sulphate in the endothelial cells of vessels leads to decreased binding of lipoprotein lipase, which results into decreased clearance of very low density lipoproteins and leads to hyperlipidemia. Similar to endothelial dys- function, the initial stage of atherosclerosis with low grade inflammation is common between MAU and cardiovascular disease $(23,24)$.

Microalbuminuria may imply a vulnerability for atherosclerosis due to its association with inflammatory and prothrombotic changes involved in endothelial dysfunction (25-29). There is conflicting evidence that MAU reflects a systemic transvascular leakage of albumin, which may be associated with leakage of lipoproteins and other macromolecules $(30,31)$. Thus, defective endothelial permeability allows lipid influx into the vessel wall causing atherosclerotic changes (32). Regarding the microvascular damage, Ebinç et al. (33) demonstrated that levels of vascular endothelial growth factor (VEGF) are higher in hypertensive patients in the presence of microalbuminuria. VEGF is the most important regulator of pathological and physiological angiogenesis and it additionally leads to increased vascular permeability, therefore it may also increase glomerular permeability and lead to MAU in hypertension.

Hypertensive patients with high urinary albumin excretion might be candidates to atherosclerotic diseases. Therefore the European guidelines underline the importance of assessing microalbuminuria as a routine measurement in every hypertensive patient (34). Nevertheless, in 2010, a joint task force of the American College of Cardiology and AHA (35) issued guidance on which novel risk factors or biomarkers, in addition to classical risk factors, might be currently considered in CHD risk prediction. The task force categorized microalbuminuria assessment as reasonable in adults with hypertension or diabetes. Thanks to its relatively low cost and wide applicability, more widespread use of this test in the diagnostic workup will help detect subsets of patients at greater risk for whom additional preventive and therapeutic treatment is advisable (36).

\section{Limitations of the study}

First, the study population is small and it doesn't allow us to make predictions on a 
large-size effect. However, this preliminary data marks an important result that needs further evaluation. Second, we used a single morning spot urine sample to assess microalbuminuria, instead of timed urine collections, which would have been preferable. However, single analysis is an established, easy, and valid screening tool in a controlled group. Its results can point towards certain medication to start with and it also brings data about the risk profile.

Third, LVH was interpreted by using only two dimensions of the wall thickness, and not the left ventricular mass index. The concordance between wall thickness and a left ventricular mass index is only 60\% (37). In addition, wall thickness tends to underestimate LVH in women and overestimate it in men. However, echocardiography, if available, should be the test of choice to assess for LVH, being much more sensitive than electrocardiography (38).

Last, there is no sustainable data about prior antihypertensive medication. It would have been of interest the assessement of ACEI/ARB medication, given the fact that an analysis of the ONTARGET trial have provided evidence for slowing the progression of renal disease demonstrated by level of microalbuminuria in at-risk patients, including those with diabetes, being treated with telmisartan or ramipril $(39,40)$. In addition, ROADMAP trial showed that pharmacological blockade of angiotensin II receptors by olmesar$\tan$ is effective in reducing the risk of new-onset albuminuria in type 2 diabetic patients (41).

\section{Conclusions}

MAU is very common in high-risk hypertensive patients, however it is often under-diagnosed and awareness of its importance as a marker of cardiovascular risk is still poor. Given its feature as a strong, early and independent marker of cardiovascular morbidity and mortality, our study highlights the importance of evaluating the presence of microalbuminuria and the need for a more aggressive medical therapy for the hypertensive patients.
Acknowledgments: DLŞ is funded by The European Social Fund, project POSDRU/107/1.5/S/78702.

Conflict of interest: None declared.

\section{References}

1. Borch-Johnsen K, Feldt-Rasmussen B, Strandgaard S, Schroll M, Jensen JS. Urinary albumin excretion. An independent predictor of ischemic heart disease. Arterioscler Thromb Vasc Biol. 1999 Aug; 19(8):1992-7

2. Wada T, Shimizu M, Toyama T, Hara A, Kaneko S, Furuichi K. Clinical impact of albuminuria in diabetic nephropathy. Clinical and experimental nephrology 2012; 16: $96-101$.

3. Fox CS, Matsushita K, Woodward M, Bilo HJG, Chalmers J, Heerspink HJ, et al. Associations of kidney disease measures with mortality and end-stage renal disease in individuals with and without diabetes: a meta-analysis. Lancet 2012; 380: 1662-1673.

4. Böhm M, Thoenes M, Danchin N, Bramlage P, La Puerta P, Volpe M. Association of cardiovascular risk factors with microalbuminuria in hypertensive individuals: the i-SEARCH global study. J Hypertens 2007; 25(11):2317-2324

5. Ibsen $\mathrm{H}$, Olsen $\mathrm{MH}$, Wachtell $\mathrm{K}$, Borch-Johnsen $\mathrm{K}$, Lindholm LH, Mogensen CE, et al. Reduction in albuminuria translates to reduction in cardiovascular events in hypertensive patients: losartan intervention for endpoint reduction in hypertension study. Hypertension 2005; 45(2):198-202

6. Parving $\mathrm{HH}$, Lehnert $\mathrm{H}$, Brochner-Mortensen J, Gomis R, Andersen S, Arner P. The effect of irbesartan on the development of diabetic nephropathy in patients with type 2 diabetes. N Engl J Med 2001; 345(12):870-878

7. Agrawal B, Berger A, Wolf K, Luft FC. Microalbuminuria screening by reagent strip predicts cardiovascular risk in hypertension. J Hypertens. 1996; 14:223-228.

8. Jensen JS, Feldt-Rasmussen B, Borch-Johnsen K, Clausen P., Appleyard M, Jensen G. Microalbuminuria in arterial hypertension: relation to cardiovascular disease and antihypertensive agents. J Hum Hypertens. 1997;11:727-732

9. Pontremoli R, Sofia A, Ravera M, Nicolella C, Viazzi F, Tirotta A, et al. Prevalence and clinical correlates of microalbuminuria in essential hypertension: The Magic Study. Hypertension. 1997; 30:1135-1143.

10. Jensen JS, Feldt-Rasmussen B, Strandgaard S, Schroll M, Borch-Johnsen K. Arterial hypertension, microalbuminuria, and risk of ischemic heart disease. Hypertension 2000; 35:898-903.

11. Vaur L, Gueret P, Lievre M, Chabaud S, Passa P. Development of congestive heart failure in type 2 diabetic patients with microalbuminuria or proteinuria: observa- 
tions from the DIABHYCAR (type 2 DIABetes, Hypertension, CArdiovascular Events and Ramipril) study. Diabetes Care 2003; 26:855-860.

12. Yuyun MF, Khaw KT, Luben R, Welch A, Bingham $\mathrm{S}$, Day NE, et al. Microalbuminuria and stroke in a British population: the European Prospective Investigation into Cancer in Norfolk (EPIC-Norfolk) population study. J Intern Med 2004; 255:247-256.

13. Lakka TA, Salonen R, Kaplan GA, Salonen JT. Blood pressure and the progression of carotid atherosclerosis in middle-aged men. Hypertension 1999; 34:51-56.

14. Schmieder RE, Schrader J, Zidek W, Tebbe U, Paar WD, Bramlage P, et al. Low-grade albuminuria and cardiovascular risk: What is the evidence? Clin Res Cardiol 2007; 96:247-257

15. Garg AX, Kiberd BA, Clark WF, Haynes RB, Clase CM. Albuminuria and renal insufficiency prevalence guides population screening: results from the NHANES III. Kidney Int. 2002; 61(6):2165-75.

16. Hillege HL, Janssen WM, Bak AA, Diercks GF, Grobbee DE, Crijns HJ, et al. Microalbuminuria is common, also in a nondiabetic, nonhypertensive population, and an independent indicator of cardiovascular risk factor and cardiovascular morbidity. J Intern Med. 2001; 249(6):519-26.

17. Mahfoud F, Ukena C, Pöss J, Bramlage P, Volpe M, Thoenes M, et al. Microalbuminuria independently correlates to cardiovascular comorbidity burden in patients with hypertension. Clin Res Cardiol. 2012 Sep; 101(9):761-6

18. Klausen KP, Parving HH, Scharling H, Jensen JS. The association between metabolic syndrome, microalbuminuria and impaired renal function in the general population: impact on cardiovascular disease and mortality. J Intern Med. 2007 Oct; 262(4):470-8.

19. de Simone G, Gottdiener JS, Chinali M, Maurer MS. Left ventricular mass predicts heart failure not related to previous myocardial infarction: the Cardiovascular Health Study. Eur Heart J 2008; 29(6):741-747

20. Gerstein HC, Mann JF, Yi Q, Zinman B, Dinneen SF, Hoogwerf B, et al.; HOPE Study Investigators. Albuminuria and risk of cardiovascular events, death, and heart failure in diabetic and nondiabetic individuals. JAMA. 2001 Jul 25; 286(4):421-6

21. Klausen K, Borch-Johnsen K, Feldt-Rasmussen B, Jensen G, Clausen P, Scharling H, et al. Very low levels of microalbuminuria are associated with increased risk of coronary heart disease and death independently of renal function, hypertension, and diabetes. Circulation. $2004 \mathrm{Jul}$ 6; 110(1):32-5

22. Kannel WB. Risk stratification in hypertension: new insights from the Framingham Study. Am J Hypertens 2000; 13(1 Pt2):3S-10S

23. Deckert T, Kofoed-Enevoldsen A, Nørgaard K, Borch-Johnsen K, Feldt-Rasmussen B, Jensen T. Microalbuminuria. Implications for micro- and macrovascular disease. Diabetes Care. 1992 Sep; 15(9):1181-91
24. Stehouwer CD, Smulders YM. Microalbuminuria and risk for cardiovascular disease: Analysis of potential mechanisms. J Am Soc Nephrol. 2006 Aug; 17(8):210611.

25. Deckert T, Feldt-Rasmussen B, Borch-Johnsen K, Jensen T, Kofoed-Enevoldsen A. Albuminuria reflects widespread vascular damage. The Steno hypothesis. Diabetologia 1989; 32:219-26.

26. Stehouwer CD, Gall MA, Twisk JW, Knudsen E, Emeis JJ, Parving HH. Increased urinary albumin excretion, endothelial dysfunction, and chronic low-grade inflammation in type 2 diabetes: progressive, interrelated, and independently associated with risk of death. Diabetes 2002; 51:1157-65.

27. Stehouwer CD, Nauta JJ, Zeldenrust GC, Hackeng WH, Donker AJ, den Ottolander GJ. Urinary albumin excretion, cardiovascular disease, and endothelial dysfunction in non-insulin-dependent diabetes mellitus. Lancet 1992; 340:319-23.

28. Festa A, D'Agostino R, Howard G, Mykkanen L, Tracy RP, Haffner SM. Inflammation and microalbuminuria in nondiabetic and type 2 diabetic subjects: The Insulin Resistance Atherosclerosis Study. Kidney Int 2000; 58:1703-10.

29. Klausen P, Feldt-Rasmussen B, Jensen G, Jensen JS. Endothelial haemostatic factors are associated with progression of urinary albumin excretion in clinically healthy subjects: a 4-year prospective study. Clin Sci (Lond) 1999; 97:37-43.

30. Jensen JS. Renal and systemic transvascular albumin leakage in severe atherosclerosis. Arterioscler Thromb Vasc Biol 1995; 15:1324-9.

31. Jensen JS, Feldt-Rasmussen B, Borch-Johnsen K, Jensen KS, Nordestgaard BG. Increased transvascular lipoprotein transport in diabetes: association with albuminuria and systolic hypertension. J Clin Endocrinol Metab 2005; 90:4441-5.

32. Garg JP, Bakris GL. Microalbuminuria: marker of vascular dysfunction, risk factor for cardiovascular disease. Vasc Med. 2002 Feb; 7(1):35-43

33. Ayerden Ebinç F, Haksun E, Ulver DB, Koç E, Erten $\mathrm{Y}$, Reis Altok K, et al. The relationship between vascular endothelial growth factor (VEGF) and microalbuminuria in patients with essential hypertension. Intern Med. 2008; 47(17):1511-6

34. Mancia G, Laurent S, Agabiti-Rosei E, Ambrosioni E, Burnier M, Caulfield MJ, et al. Reappraisal of European guidelines on hypertension management: a European Society of Hypertension Task Force document. J Hypertens 2009; 27(11):2121-2158

35. Greenland P, Alpert JS, Beller GA, Benjamin EJ, Budoff MJ, Fayad ZA, et al. 2010 ACCF/AHA guideline for assessment of cardiovascular risk in asymptomatic adults: Executive summary. A report of the American College of Cardiology Foundation/American Heart Association Task Force on Practice Guidelines. Circulation. 2010; 
122:2748-64

36. Viazzi F, Leoncini G, Pontremoli R. Global cardiovascular risk assessment in the management of primary hypertension: the role of the kidney. Int J Hypertens. 2013; 2013:542646.

37. Leibowitz D, Planer D, Ben-Ibgi F, Rott D, Weiss AT, Bursztyn M. Measurement of wall thickness alone does not accurately assess the presence of left ventricular hypertrophy. Clin Exp Hypertens 2007; 29:119-125.

38. Bauml MA, Underwood DA. Left ventricular hypertrophy: an overlooked cardiovascular risk factor. Cleve Clin J Med. 2010 Jun; 77(6):381-7.

39. Mann JF, Schmieder RE, Dyal L, McQueen MJ, Schumacher H, Pogue J, et al. TRANSCEND ${ }^{\circledR}$ (Telmisartan Randomised Assessment Study in ACE Intolerant Sub- jects with Cardiovascular Disease) Investigators: Effect of telmisartan on renal outcomes: a randomized trial. Ann Intern Med 2009; 7:1-10.

40. Mann JF, Schmieder RE, McQueen M, Dyal L, Schumacher H, Pogue J, et al. The ONgoing Telmisartan Alone and in combination with Ramipril Global Endpoint Trial (ONTARGET®) Investigators: Renal outcomes with telmisartan, ramipril, or both, in people at high vascular risk (the ONTARGET® study): a multicentre, randomised, double-blind, controlled trial. Lancet 2008; 372:547-53 41. Chatzikyrkou C, Menne J. Update on the ROADMAP clinical trial report: olmesartan for the prevention or delay of microalbuminuria development in type 2 diabetes. Expert Rev Cardiovasc Ther. 2012 Sep;10(9):1087-92. 